\title{
VYUŽITÍ SVĚTLOPROPUSTNÝCH MATERIÁLŮ VE STAVEBNÍCH KONTRUKCÍCH
}

\section{USING OF LIGHT-PERMEABLE MATERIALS IN BUILDING STRUCTURES}

\author{
Ing. Adam Boháček ${ }^{\text {*; }}$ Ing. Michal Brandtner ${ }^{1}$ \\ ${ }^{1}$ Vysoké učení technické v Brně, Fakulta stavební, Veveři 331/95, 60200 Brno, Česká republika \\ *korespondenční autor: bohacek.a@fce.vutbr.cz
}

\begin{abstract}
ABSTRAKT CZ
Tento článek shrnuje poznatky o novince na poli stavebnictví - světlopropustném betonu. Koncept betonu se světlopropustnými prvky se poprvé, v dobře proveditelné formě, objevil v mad'arsku pod obchodním názvem LiTraCon. Jedná se o betonové dílce, v nichž jsou jako světlopropustné prvky využity skleněná optická vlákna. Dále pak zmiňuje český betonový výrobek, LiCrete, u kterého je využito mřižky ze světlopropustného UV stabilního plexiskla. V závěru článku je pak popsán experiment, při kterém se autor článku pokusil zhotovit vzorky světlopropustného betonu, a to za použití tyčinek z optického skla a optických vláken.
\end{abstract}

Klíčová slova: LiTraCon, LiCrete, světlopropustný beton, optická vlákna, optické sklo

\section{ABSTRACT}

This article summarizes knowledge about a novelty in the field of construction - light-transmitting concrete. The concept of concrete with light-transmitting elements first appeared in a well-feasible form in Hungary under the trade name LiTraCon. These are concrete parts in which glass optical fibers are used as light-transmitting elements. He also mentions a Czech concrete product, LiCrete, which uses a grid of light-transmitting UV stable plexiglass. At the end of the article, an experiment is described in which the author of the article tried to make samples of light-transmitting concrete using optical glass rods and optical fibers.

Key words: LiTraCon, LiCrete, light-transmitting concrete, optical fibers, optical glass

\section{1 ÚVOD}

Již od počátků stavebnictví zde panuje snaha o co největší využití přirozeného světla ve vnitřních prostorách budov. Tohoto bylo v minulosti dosahováno především pomocí různých otvorů, které byly v pozdějších dobách překrývány látkami či ještě později vyplněny skleněnými tabulkami. Ve středověku došlo k rozvoji technologií zpracování skla, které se projevilo mimo jiné na zdobených mozaikových oknech, v té době hojně používaných v sakrálních stavbách.

I nyní se při navrhování a realizaci staveb snažíme o co nejvíce přírodně prosvětlený interiér. Dnes $\mathrm{k}$ tomu ale již může, díky pokročilým technologiím, použít nových materiálů a nemusíme se nutně upínat k využívání oken. Mezi novinky posledních let na poli stavebnictví patří tzv. světlopropustný beton. Jedná se o materiál, který je schopen pomocí implementovaných př́měsí v betonu vést světlo. $\mathrm{V}$ tomto článku se zaměříme na tři konkrétní př́iklady použití světlopropustných materiálů v betonu, a 
to na světloprobustný beton s využitím optického skla, dále LiTraCon, který je mad’arského původu a pro vedení světelného záření využívá skleněných optických kabelů, a na výrobek LiCrete, jež má původ český a jako vodič světla využívá plexisklové mřížky. [1,2]

Autorem tohoto článku byl proveden pokus o zreplikování výroby světlopropustného betonu v klasických laboratorních podmínkách. Cílem tohoto experimentu bylo zhodnocení složitosti výroby takového betonu a jeho schopnosti skutečně propouštět světlo.

\section{METODY}

\subsection{Shrnutí výzkumu $\mathrm{k}$ tématu}

Světlo propustný beton, je takový materiál, který kromě svých charakteristických vlastností betonu, mezi které patř́ např́íklad jeho pevnost, má i vlastnost propouštět světlo. Tato vlastnost je tomuto materiálu propůjčena skrze prostředek, který je vkládán do betonu. Tímto prostředkem je myšleno optické sklo, optické kabely, nebo dokonce plexisklo jako v př́padě výrobku Licrete.

\subsubsection{Optické sklo}

S potřebou vytvořit nosnou konstrukci, která by propouštěla denní světlo do interiéru vznikla otázka, jak toho docílit. Jako první se do betonu začalo vkládat sklo, které bylo známo už od středověku, avšak s postupem doby a rozvoje zpracování skla to bylo optické sklo ve formě tyčinek, které bylo umist’ováno do těchto konstrukcí, aby bylo docíleno světlo propustnosti betonu. Tyčinky optického skla jsou umístěny v konstrukci tak, že propojují obě strany konstrukce, a tak zajištují světlo propustnost konstrukce. S postupem času a vývojem stavebních materiálů se do světlo propustných betonů začal jako prostředek zajišt'ující průchod světla používat skleněné optické kabely nebo plexisklo. [1,2]

\subsubsection{LiTraCon}

Jak již bylo zmíněno v úvodu tohoto článku Litracon vznikl v mad’arsku, a to již v roce 2001, kdy se nechal mad’arský architekt Áron Losonczi inspirovat umělci, kteří využívali úlomky skla a umist'ovali je do masivního betonu, aby docílili vzniku nových vlastností, jednou z nich je právě světlopropustnost. Ve spolupráci s mad’arskou univerzitou vynalezl světlo propustný beton a nazval ho Litracon. Tento název je zkratka anglického sousloví Light Transmitting Concrete neboli beton propouštějící světlo.

Tento materiál se skládá z jemnozrnného betonu a skleněných vláken. Poměr těchto dvou složek je 96 $\%$ jemnozrnného betonu a pouze $4 \%$ skleněných vláken. Tato vlákna jsou ve hmotě betonu paralelně uspořádány od jedné strany prvku ke druhé. Tímto usporádáním skleněných vláken se docílí stejné světelné informace na obou stranách prvku. Litracon je vyráběn ve formě prefabrikovaných bloků určených $\mathrm{k}$ další prefabrikované výstavbě. Jelikož beton a skleněná vlákna vytvářejí homogenní hmotu není nijak narušena pevnost hotového výrobku, a proto u prvních sériové vyráběných bloků dosahovali pevnosti v tlaku 32 až 49 Mpa a je tedy možné využívat tyto bloky pro nosné konstrukce.

První realizace z Litraconu byla provedena v roce 2002 ve Stockholmu. Jednalo se o pochozí dlažbu náměstí s použitím bloků o rozměrech $350 \times 350 \times 50 \mathrm{~mm}$, která se zdála být obyčejnou betonovou dlažbou, avšak v noci se rozzářila působením světelných zdrojů umístěných pod touto dlažbou. Následovali další realizace naprríklad v roce 2003 byly realizovány stěny kostela taktéž ve Stockholmu, kde tloušt'ka světlo propustného betonu byla úctyhodných $500 \mathrm{~mm}$. Současná limitní hodnota tloušt'ky bloku je až 3000 mm a velikost takovéhoto bloku je 300 x 600 mm. Avšak úplně první sériově vyráběným produktem se stala lampa $\mathrm{z}$ bloků světlo propustného betonu nazvaná Litracube. [3,4] doi.org/10.51704/cice.2020.vol6.iss2.pp13-20 


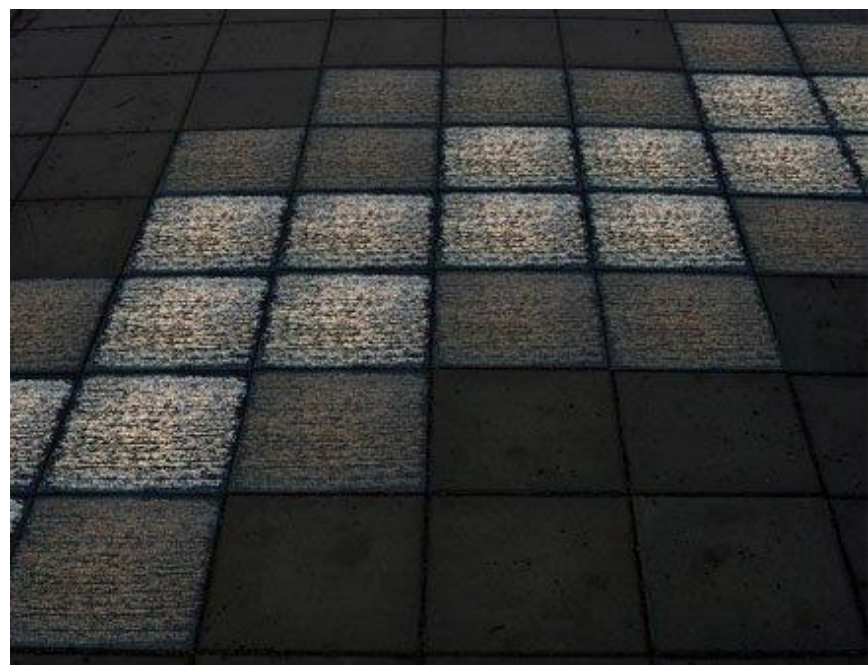

Obr. 1 Realizace exteriérové dlažby z Litraconu [5]

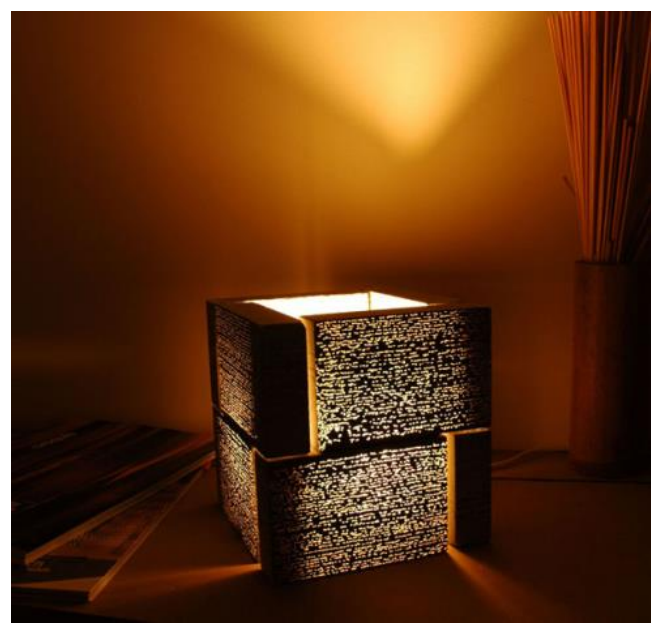

Obr. 2 Lampa Litracube [6]

\subsubsection{LiCrete}

Světlo propustný beton Licrete pochází z dílny dvou českých autorů, a to Jiřího Peterse a Ladislava Eberla, kteří dali dohromady beton jako tradiční stavební materiál a plexisklo a vznikl světlo propustný beton Licrete. Spojením těchto dvou materiálů vznikl produkt, který vykazuje vlastnosti betonu jako je pevnost $60 \mathrm{~N} / \mathrm{mm}^{2}$ po 28 dnech a zároveň propouští světlo. Světla denního či umělého dokáže přenést více jak $20 \%$.

Licrete je vyráběn ve formě cihel o rozměrech $300 \times 150 \times 75 \mathrm{~mm}$ a půlcihel o rozměrech $150 \times 150 \times 75$ $\mathrm{mm}$ opatřených perem a drážkou, pro snadnou realizaci konstrukcí. K realizaci z cihel Licrete se přistupuje jako při stavbě stěny z kusového staviva, kdy jsou jednotlivé cihly opatřeny perem a drážkou, na kterou se nanáší lepidlo.

Proces výroby Licrete představuje potřebu ruční práce, a to především při uložení plexisklových členů do forem. Po sestavení forem následuje uložení samozhutnitelného betonu a začíná fáze zrání, která trvá 24 hodin, při kterých je nutné beton vhodně ošetřovat. Po jednom dni jsou formy rozebrány a prvky jsou 
uloženy do zracích komor, kde zrají po dobu 7 dnů a poté jsou prvky broušeny a leštěny ve vodní lázni, a to $\mathrm{z}$ toho důvodu, aby nedocházelo $\mathrm{k}$ přehřívání prvků.

Produkt Licrete se s výhodou používá tam, kde je třeba realizovat stěnu z masivního materiálu a zároveň nosnou, ale zároveň je kladen důraz na přenášení světla. Dokonce z hlediska úspory elektrické energie za umělé osvětlení a př́ísunu denního světla do budov, lze prohlásit, že tento produkt má př́znivý vliv na životní prostředí a zároveň plní funkci architektonickou. [7,8]

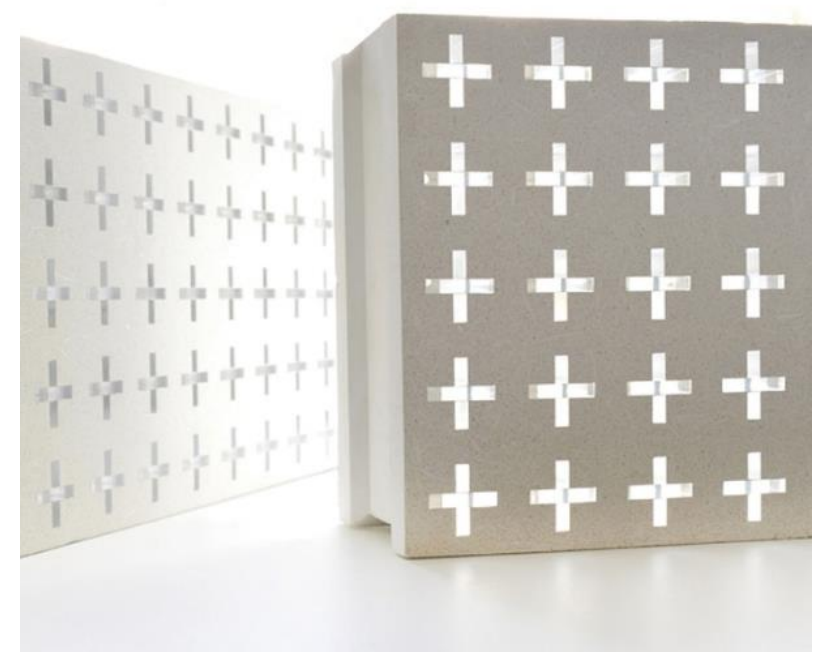

Obr. 3 Cihla Licrete [7]

\subsection{Experiment}

V rámci výzkumu byl proveden pokus o zreplikování světlopropustného betonu, který byl proveden v běžných laboratorních podmínkách. Tento výzkum si kladl za cíl zhotovení světlopropustného betonu s prvky optického skla a optických skleněných vláken. Postup výroby vzorků těchto betonů a výsledky jsou popsány níže.

\subsubsection{Světlopropustný beton - optické sklo}

Sklo je amorfní (její částice nejsou uspořádány do pravidelné krystalové mřřžky) pevná a křehká hmota, většinou anorganická, která vznikla ochlazením taveniny, aniž by krystalizovala. Optické sklo musí být dokonale homogenní, izotropní, čisté a s co nejmenší disperzí. Suroviny musí být dokonale čisté a přesně navážené, aby bylo dosaženo požadovaných optických vlastností. Většina optických skel jsou skla křemičitá. Různými prrísadami se dosahuje požadovaných optických, mechanických, chemických a jiných vlastností. Tvrdost optických skel je různá. Obecně platí, že vysoko indexová skla jsou měkčí a chemicky méně odolná. Sklo má přibližně desetkrát vyšší pevnost v tlaku než v tahu. Proto snadněji praská při prudkém ochlazení, kdy je povrchová vrstva namáhána tahem než při prudkém zahřátí. Trhlinky ve skle velmi zmenšují jeho pevnost, proto je důležité leštění, zvláště žárové. Pružnost skla je velmi malá, křehkost naopak vysoká. Sklo je křehčí než kovy, ale méně křehké než porcelán, kamenina, beton. Tvrdost se rovná přibližně 5 až 7 stupňům Mohsovy stupnice nerostů. Nejtvrdší je čisté křemenné sklo a některá borokřemičitá skla. Mezi nejměkčí skla patř́i skla vysoko indexová s vysokých obsahem PbO. Co se týká tepelné a elektrické vodivosti, sklo patří mezi izolanty. Mezi skly je nejlepším vodičem 
tepla čisté křemenné sklo a má i malou tepelnou roztažnost. Za vysokých teplot, kdy se mohou ve skle volně pohybovat sodíkové ionty, je sklo pro elektrický proud vodičem.

Při výrobě tohoto typu betonu byl autorem použit klasický hobby beton, dostupný v českých hobby marketech a tyčinky z optického skla o průměru $1 \mathrm{~cm}$.

Jako forma (Obr. 4) pro odlití betonového kvádru se světlopropustnými prvky bylo využito dílů, které byly vytištěny na 3D tiskárně pomocí PLA struny. Forma z tohoto materiálu je vhodná zejména z toho důvodu, že betonové těleso lze velmi dobře vyklopit a nedochází $\mathrm{k}$ jeho poškození při násilném sundávání formy.

Nejprve byly do formy umístěny optické prvky (Obr. 5), v tomto př́padě tedy tyčinky z optického skla, které byly následně zality betonem (Obr. 6). Po zhutnění byl vzorek ponechán při pokojové teplotě a po úplném vyzrání, ke kterému došlo po 28 dnech byl vyjmut $\mathrm{z}$ formy. Výsledek je možné vidět na obrázku Obr.7.

\subsubsection{Světlopropustný beton - optická skleněná vlákna}

Optické vlákno je tenké vlákno ze skla nebo ve speciálních př́ípadech z průhledného plastu, které je schopné přenášet po své délce elektromagnetické vlny, a to i na značné vzdálenosti. Základním principem fungování optických vláken je fyzikální jev nazývaný totální reflexe neboli absolutní odraz světla. K tomu dochází, pokud světlo prochází z opticky hustšího prostředí do opticky řidšího a rozhraní mezi těmito dvěma prostředími dosáhne pod úhlem menším než kritickým. $\mathrm{V}$ takovém případě se veškerá světelná energie odrazí zpět do opticky hustšího prostředí. Velikost kritického úhlu závisí na poměru indexů lomu obou prostředí. Sklo má index lomu výrazně vy̌̌ší než vzduch a je tedy opticky hustší. Proto už obyčejné skleněné vlákno funguje jako světlovod, dochází v něm ale k velkým ztrátám, a tedy i k útlumu světla, pro použití na průsvitný beton tedy není ideální. Nejlepší je použití vláken $\mathrm{s}$ jádrem s vyšším indexem lomu obklopeným pláštěm s pouze malinko nižším indexem lomu.

Při výrobě tohoto typu světlopropustného betonu bylo postupováno velmi podobně jako u předešlého typu. Jako vodič světla byl využit optické skleněné vlákno o průměru $1 \mathrm{~mm}$. Forma (Obr. 8) byla vyrobena, stejně jako v minulém případě, na 3D tiskárně pomocí PLA struny.

K upevnění optických vláken do formy bylo využito tavné pistole (Obr. 9). Po jejich umístění byl do formy vlit beton (Obr. 10). Zhutnění v tomto případě bylo poněkud obtížné, vzhledem $\mathrm{k}$ velké hustotě optických vláken ve vzorku, proto bylo provedeno pouze sklepáním o podložku.

Po úplném vyzrání betonu, po 28 dnech, byl vzorek odbedněn a výsledek je možné vidět na obrázku Obr. 11.

\section{VÝSLEDKY}

\subsection{Světlopropustný beton - optické sklo}

Během experimentu byl vytvořen funkční vzorek světlopropustného betonu s prvky optického skla. Výsledek, tedy hotový vzorek je možné vidět na obrázku Obr. 7. 


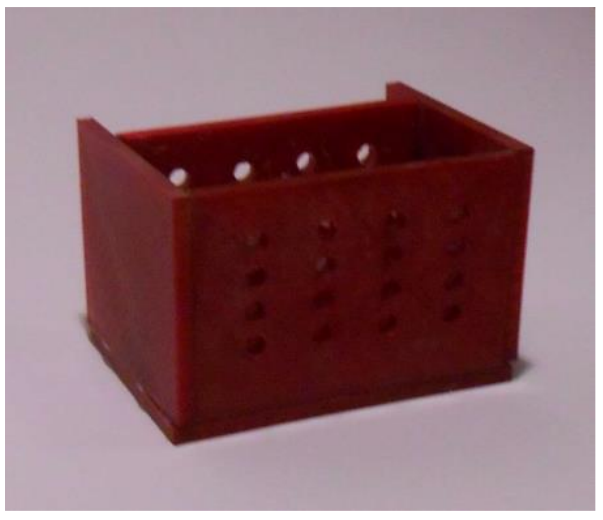

Obr. 4 Forma

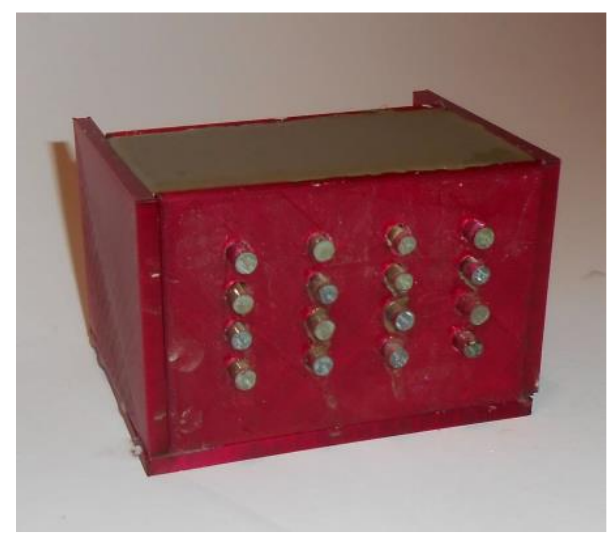

Obr. 6 Betonáž vzorku

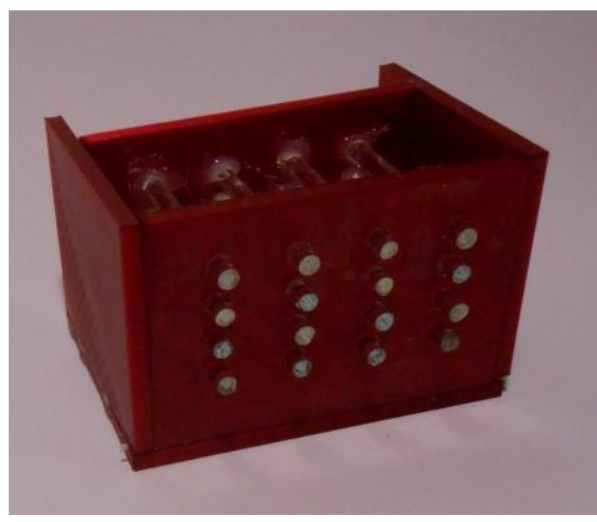

Obr. 5 Vložení optických prvků

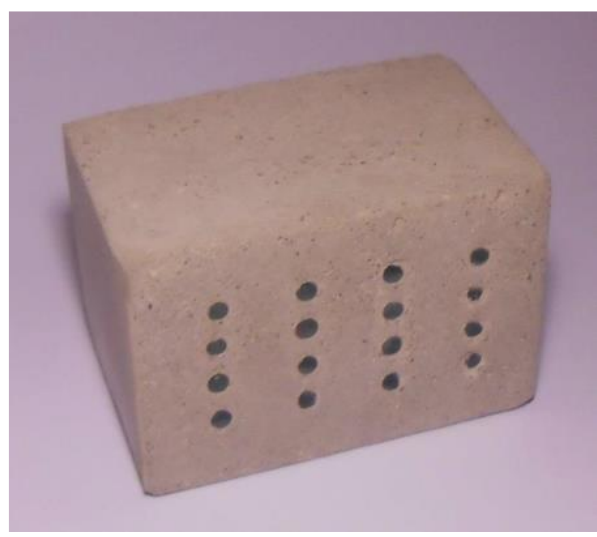

Obr. 7 Hotový vzorek

\subsection{Světlopropustný beton - optická skleněná vlákna}

I v případě světlopropustného betonu s optickými skleněnými vlákny byl zhotoven vzorek. Tento je možné vidět na obrázku Obr. 11.

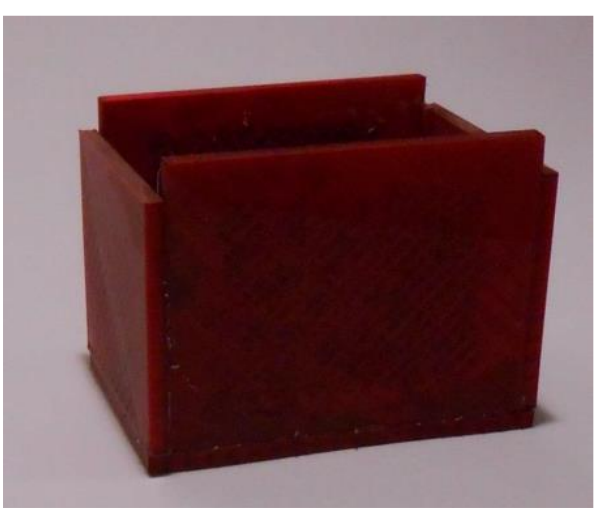

Obr. 8 Forma

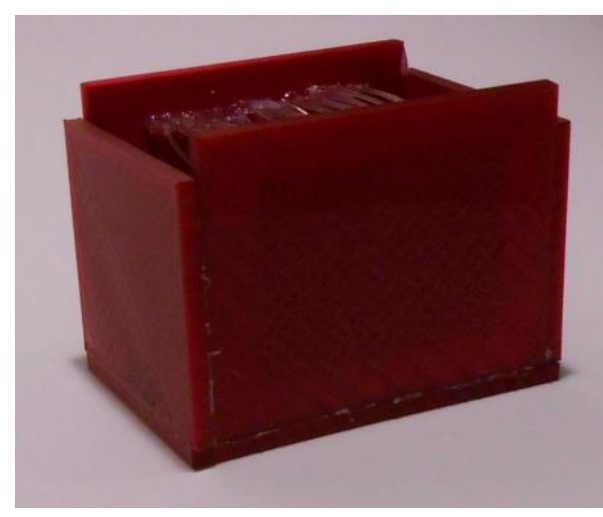

Obr. 9 Upevnění optických vláken 


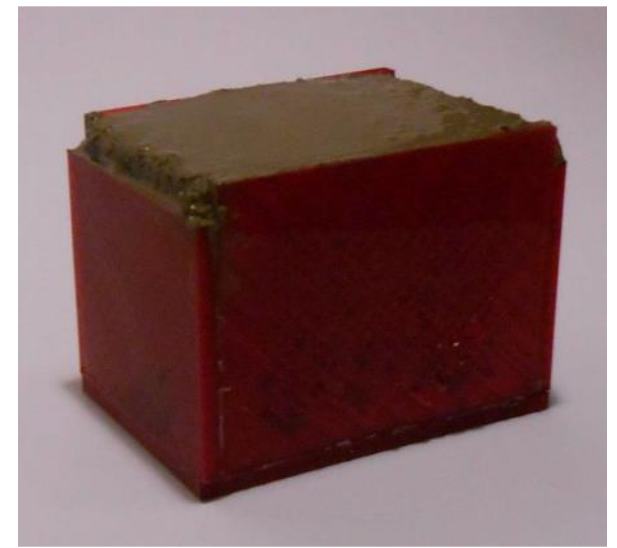

Obr. 10 vylití formy betonem

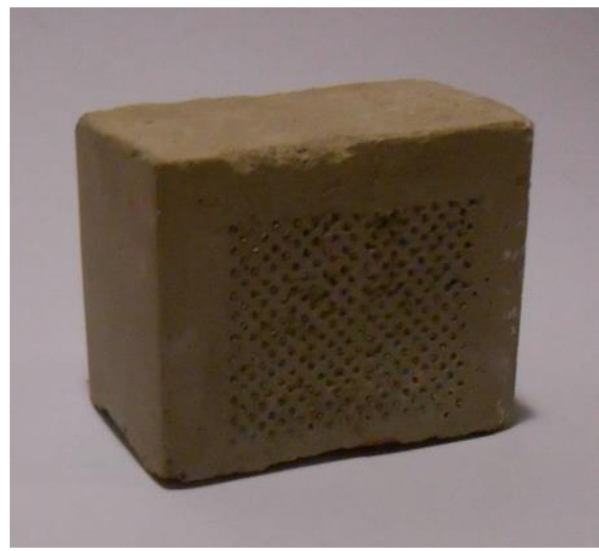

Obr. 11 Hotový vzorek

\section{ANALÝZA}

U obou typů světlopropustného betonu se podařilo v laboratorních podmínkách vyrobit funkční vzorky. Tyto vzorky obsahovaly světlopropustné elementy, které byly umístěny takovým způsobem, aby propouštěli co nejvíce světla. U obou vzorků se tento záměr podařilo naplnit a světlopropustnost byla opravdu značná.

\section{ZÁVĚR}

V laboratorních podmínkách lze vyrobit jak světlopropustný beton typu LiTraCon, tak podobné typu LiCrete. Nicméně takováto kusová výroba je velmi náročná, a to jak složitostí postupu, finanční náročností tak i vysokými časovými nároky na výrobu.

\section{Poděkování}

Příspěvek vznikl za podpory Standardního specifického výzkumu Vysokého učení technického v Brně s registračním číslem FAST-S-20-6338 a Juniorského specifického výzkumu s registračním číslem FAST-J-20-6359. 


\section{Použitá literatura}

[1] CHIEW, Shing Mei, Izni Syahrizal IBRAHIM, Mohd Azreen MOHD ARIFFIN, Han-Seung LEE a Jitendra Kumar SINGH. Development and properties of light-transmitting concrete (LTC) - A review. Journal of Cleaner Production. 2021, 284. ISSN 09596526. Dostupné z: doi:10.1016/j.jclepro.2020.124780

[2] Kumar, A., Ahlawat, R. Experimental Study on Light Transmitting Concrete, 2017, International Journal of Innovative Science, Enginering \& Technology, 4(6), Pages 201-210, ISSN 2348-7968

[3] Litracon [online]. 2021 [cit. 2021-01-20]. Dostupné z: http://www.litracon.hu/en

[4] Průsvitný beton - LiTraCo [online]. 2014 [cit. 2021-01-19]. Dostupné z: https://www.asbportal.cz/stavebnictvi/zaklady-a-hruba-stavba/cement-a-beton/prusvitny-beton-litracon

[5] Materialsresourcecenter [online]. 2010 [cit. 2021-01-19]. Dostupné z: https://materialsresourcecenter.wordpress.com/2010/09/17/litracon/

[6] Concrete design blog: Litracube lamp [online]. 2011 [cit. 2021-01-19]. Dostupné z: https://concretedesignblog.wordpress.com/2011/03/06/litracube-lamp/

[7] Licrete: Transparent concrete [online]. 2021 [cit. 2021-01-19]. Dostupné z: https://licrete.com/

[8] LiCrete® - kombinace nadčasovosti a efektivity [online]. 2015 [cit. 2021-01-19]. Dostupné z: https://www.stavebnictvi3000.cz/clanky/licrete-kombinace-nadcasovosti-a-efektivity 